DOI: $\underline{\text { https://doi.org/10.24867/06KG04Gavrilovic }}$

\title{
ЗОНИРАЊЕ ПОЉОПРИВРЕДНИХ ПАРЦЕЛА УПОТРЕБОМ ВЕГЕТАЦИОНИХ ИНДЕКСА
}

\section{ZONING OF AGRICULTURAL FILEDS USING VEGETATION INDICES}

\author{
Милан Гавриловић, Факултет техничких наука, Нови Сад
}

\section{ОбЛаст - ГЕОДЕЗИЈА И ГЕОМАТИКА}

Кратак садржај - У овом раду описан је поступак класирања пољопривредног земљишта у класе, на основу стања вегетације. Добијени производи су затим дистрибуирани кроз трослојну GIS архитектуру и приказани на геопорталу.

Кључне речи: Даљинска детекичија, Sentinel 2, GIS, визуелизаиија, квалитет земљишта

Abstract - In this paper, I've described the procedure of classifying agricultural land into classes depending on a state the vegetation is in. Obtained products have been then distributed through the three-tier GIS architecture and then displayed on geoportal.

Keywords: Remote sensing, Sentinel 2, GIS, visualization, quality of land

\section{1. УВОД}

Повећањем броја светског становништва јавља се потреба за повећањем пољопривредне производње што доводи до потребе за побољшањем управљања светским пољопривредним ресурсима.

Са порастом броја сателита и сензора за праћење Земље, повећане су могућности за праћење стања усева. Са тиме расте и наше знање о агрономским параметрима који прате одређену биљку. Основни принцип праћења усева је кроз различите вегетационе индексе, који се генеришу различитим комбинацијама таласних дужина одговарајућег спектра [1].

Пре сетве или садње било које биљне врсте потребно је добро упознати карактеристике изабраног земљишта. У истом земљишту могу да расту различите биљке, неке ће бити бујне, разгранате, са обиљем плодова, док ће друге остати кржљаве, слабе бујности и родности. Циљ проучавања квалитета земљишта је проналажење оптималних мера управљања ради побољшања функција земљишта.

Сателитским снимањем обезбеђују се подаци сателитских снимака различитог квалитета за примену у пољопривреди. Информације добијене правилном обрадом, анализом и екстракцијом података из сателитских снимака представљају значајан ресурс за многе системе одлучивања у привреди и науци.

\section{NAPOMENA:}

Овај рад је проистекао из мастер рада чији ментор је био др Душан Јовановић, доцент.

\section{2. ДАЉИНСКА ДЕТЕКЦИЈА}

Даљинска детекција (теледетекција, даљинско истраживање) је метода прикупљања информација о неком објекту или феномену у већем или мањем опсегу помоћу уређаја за снимање или истраживање у реалном времену који је бежичан или није у физичком или блиском контакту са објектом (тј. помоћу терестричких уређаја, авиона, хеликоптера, свемирске летелице, сателита или брода) [2].

Циљ даљинске детекције је брзо и економично добијање прецизних информација о релативно великим подручјима. Анализирањем серије снимака могуће је пратити и регистровати: дневне, сезонске и годишње промене неке појаве. Објекти даљинске детекције су сви елементи Земљине површине и атмосфере у видном пољу сензора.

\subsection{Sentinel 2}

Sentinel 2 представља мисију за посматрање Земље, која је развијена од стране Европске свемирске агенције, као део програма Copernicus чији је основни задатак да врши терестричка посматрања како би се пружила подршка системима који се баве праћењем шума, променама Земљаног покривача и контролисањем стања приликом природних непогода.

Мисија се базира на констелацији два идентична сателита Sentinel $2 A$ и Sentinel $2 B$, која се налазе у истој орбити под углом од $180^{\circ}$ један у односу на други. Sentinel $2 A$ је лансиран 23. јуна 2015. године, након чега је лансиран и Sentinel 2B, 7. марта 2017. године [3].

Сваки од сателита Sentinel 2 мисије има оптички и инструмент способан да снима у 13 спектралних опсега: 4 бенда са 10 m, 6 бендова са 20 m и 3 бенда са $60 \mathrm{~m}$ просторне резолуције. Ширина орбиталне траке износи $290 \mathrm{~km}$.

\section{3. ВЕГЕТАЦИОНИ ИНДЕКСИ}

Вегетациони индекси представљају математичке комбинације или трансформације спектралних опсега које наглашавају спектралне особине зелених биљака, тако да се оне разликују од других карактеристика слике [4].

Другим речима, вегетациони индекси служе да појачају вегетациони сигнал. Пројектовани су за мерење просторних и временских промена вегетације на регионалном, континенталном и глобалном нивоу на вишегодишњој и сезонској основи. 
Вегетациони индекси су корисни у откривању сваке врсте промене вегетације, без обзира на врсту промене.

То може бити промена у биофизичком параметру, саставу врста, стресу, коришћењу земљишта или комбинација промена.

\section{4. ГЕОПОРТАЛИ И ВИЗУЕЛИЗАЦИЈА ПРОСТОРНИХ ПОДАТАКА}

\section{1. Трослојна архитектура}

Дистрибуција геопросторних података врши се кроз трослојну GIS архитектуру (Слика 1.). Трослојна архитектура развијена је еволуцијом архитектуре клијентских сервера како би се превазишли њени недостаци. Апликације су подељене у три логички независна слоја који комуницирају путем интерфејса:

1. Презентациони слој је најближи кориснику и садржи кориснички интерфејс,

2. Средњи слој садржи пословну логику система,

3. Слој података.

Са таквом архитектуром сваки слој комуницира само са слојем који се налази и непосредно испод њега и има тачно дефинисану функционалност коју обавља.

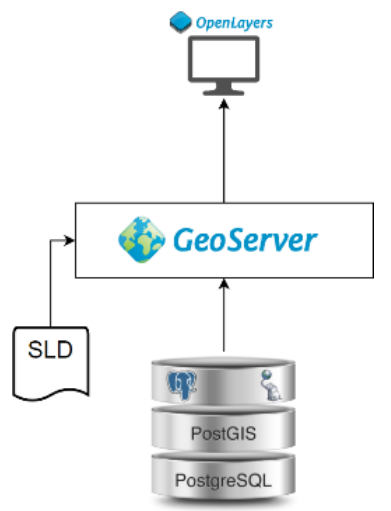

Слика 1. Трослојна GIS архитектура

Корисник подноси захтев кроз презентациони слој пословној логици система података. Слој пословне логике система проналази тражене податке из слоја података и шаље их презентацијском слоју, који га након пријема обликује и приказује кориснику.

\section{2. Геопортал}

Геопортал је кориснички интерфејс ка колекцији online геопросторних ресурса, који укључују скупове података и сервисе. Служи за приказ просторних података, њихов преглед, измену и претрагу. У суштини геопортал је интернет портал који представља географске информације од различитих извора у јединственој форми [5].

\section{5. СТУДИЈА СЛУЧАЈА}

Практични део рада се састоји из неколико делова. Наиме, први део се односи на одабир периода из којих ће бити узимани сателитски снимци, спрам фенофаза сваке засејане пољопривредне културе. Након тога извршена је обрада и класификација сателитских снимака у Google Earth Engine-y, након чега су добијене класе земљишта. На крају су сви добијени продукти, кроз трослојну архитектуру, приказани на геопорталу.

\section{1. Избор карактеристичних периода пољопривредних култура}

На самом почетку потребно је животни циклус биљке поделити у одређени број фаза. Како се у овом раду врши класификација земљишта на основу стања вегетације, период након ницања и пре зрења биљке неће бити узиман при овој анализи.

Да бисмо дефинисали периоде почетка и краја одреЂене фазе, коришћена је временска серија NDVI индекса. Са слике 2. видимо да са растом биљке расту и вредности NDVI индекса, а непосредно пре зрења те вредности почињу да опадају.

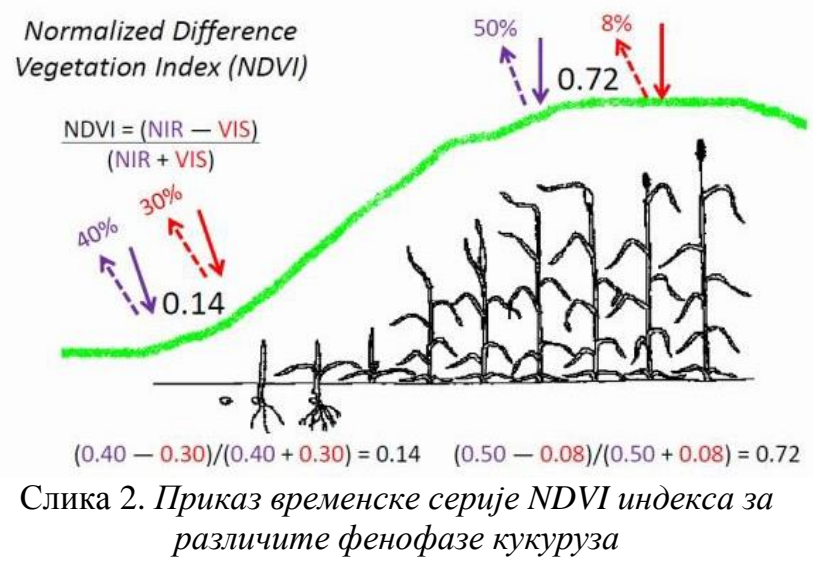

\section{2. Обрада података у Google Earth Engine-y}

Након што је извршена подела животног циклуса сваке пољопривредне културе на четири периода, приступа се даљој обради изабраних снимака за сваки период у Google Earth Engine-y.

Google Earth Engine (GEE) је напредна платформа за геопросторну обраду засновану на облаку, дизајнирана углавном за анализу података о окружењу планетарних размера.

Пре било какве употребе изабраних сателитских снимака неопходно је урадити одређен предроцесинг, то јест неопходно је извршити неке корекције над снимцима. Како су у овом раду коришћени снимци нивоа 2А над којима су већ извршене одређене корекције, било је потребно извршити само ресамплинг свих бендова на $10 \mathrm{~m}$. Поред овога употребљен је и алгоритам за маскирање и елиминацију облака.

Следећи корак је формирање вегетационих индекса. Према препорукама са сајта Index DataBase [6], који представља специјализовану базу података са великим бројем вегетационих индекса, а за одређену апликацију и сензор, дошло се до следећих вегетационих индекса: NDVI, NDVI690-710, ARVI2, LCI, SAVI.

Након тога приступамо класификацији свих срачунатих вегетационих индекса, у претходно дефинисани број класа. Како сви индекси дају веће вредности на местима где је гушћа вегетација, класификација је урађена тако што је првих 20\% од укупног броја пиксела сврстано у пету класу, то јест класу која представља најлошије земљиште, следећих 20\% у четврту класу итд. 
Овај поступак је потребно поновити за све вегетационе индексе и све периоде.

После овако извршене класификације сваког појединачног индекса врши се рачунање коначних класа за сваки од четири изабрана периода, а на основу свих претходно класификованих индекса, за тај период.

Пошто смо добили класе за сваки од четири животна циклуса сваке пољопривредне културе, на основу та четири растера формираћемо коначне класе за једну годину.

Како се биљка у првом изабраном периоду, након клијања, још увек није у потпуности развила, а у последњем четвртом периоду је пред сазревањем, јасно је да ће снимци из ова два животна циклуса биљке дати нешто другачије вредности класа од друга два снимка добијена из периода када је биљка била на врхунцу свог развоја. Да би превазишли овај проблем потребно је доделити тежине сваком животном циклусу биљке. Јасно је да ће већи утицај на коначни изглед класа имати они снимци којима је додељена већа вероватноћа, док ће мањи утицај имати они снимци са мањом вредношћу вероватноће.

Како би се елиминисао ефекат „соли и бибера“, из растер који за вредности пиксела садржи вредности броја класе којој припада земљиште, користи се неки од алгоритама за генерализацију. У овом раду коришћен је Majority филтер.

Претходно описаним поступком дошли смо до класа земљишта на основу вредности вегетационих индекса, то јест на основу стања биљке, за период од годину дана (Слика 3.).

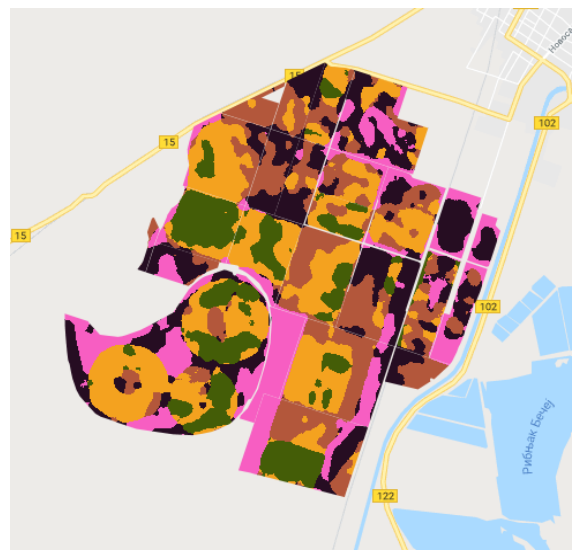

Слика 3. Растерски приказ класа за групу париела у опитини Бечеј за 2017. годину у GEE

Овако добијени растер је векторизован након чега је у $Q G I S-y$ урађено глачање ивица и рекласификација, односно брисање полигона са мањом вредности површине од унапред дефинисане. За ову анализу граница je постављена на 0.5 ha, па су тако сви полигони мањи од ове вредности елиминисани.

\section{3. Приказ и дистрибуција добијених података}

Као што је већ речено приказ и дистрибуција за све добијене податке извршена је кроз трослојну GIS архитектуру.

За потребе овог рада коришћена је PostgreSQL база података, са PostGIS проширењем, у коју су учитани претходно добијени векторски подаци.
Сви подаци из базе су публиковани на GeoServer где су им додељени одговарајући стилови употребом SLD-a (Styled Layer Descriptor). SLD је XML шема специфицирана од стране OGS (Open Geospatial Consortium) за стилизацију приказа слојева мапе. Користи се за приказ растерских и векторских података. Такође уз помоћ GeoServer- $a$ креирани су $O G S$ сервиси.

Геопортал на ком су приказани подаци формиран је употребом HTML-a, CSS-a u JavaScript-a (Слика 4.).

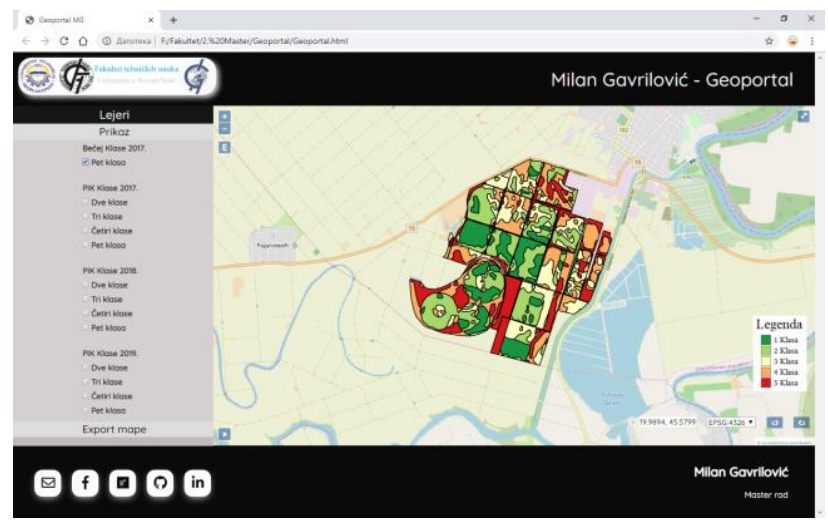

Слика 4. Векторски приказ класа за групу парцела у општини Бечеј за 2017. годину на геопорталу

\section{4. Тестирање алгоритма}

Због тога што при касирању земљишта већих површине третирамо групу парцела исте пољопривредне културе као једну парцелу, то јест зонирање вршимо на основу минималне и максималне вредности индекса свих парцела са истом пољопривредном културом, морамо поседовати тачне податке о гајеној биљци за сваку годину. Како улазни подаци нису са сигурношћу били апсолутно тачни, морало се наћи друго решење за анализу овог алгоритма.

Да би се извршила верификација алгоритма за класификацију земљишта неопходно је са сигурношћу познавати пољопривредну културу на изабраној локацији за временски период од неколико година.

У овом раду верификација је извршена на основу података за парцелу бр. 21247 која се налази у катастарској општини Бечеј. На овој парцели се 2017. године налазила шећерна репа, док је 2018. и 2019. године био засејан кукуруз.

На основу претходно осмишљеног алгоритма и апсолутно тачних улазних података, класификација земљишта ове пољопривредне парцеле је извршена у две класе.

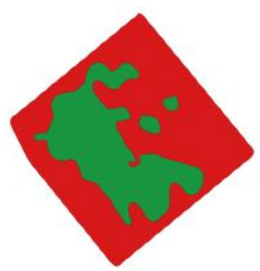

a)

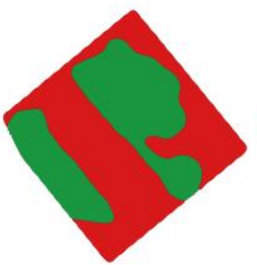

б)

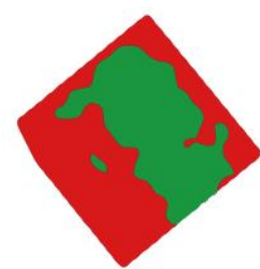

ц)
Слика 5. Векторски приказ класа за париелу бр. 21247 за 2017. (а), 2018. (б) и 2019. (и) годину

Зеленом бојом је приказано земљиште прве класе, док је црвеном бојом приказано земљиште друге класе. Као што можемо видети постоје преклапања класа за 
2018. и 2019. годину, док је у поређењу са ове две године просторни распоред класа из 2017. године другачији са малим преклапањима између класа.

Један од могућих разлог постојања различитих просторних распореда класа земљишта, за три анализиране године, јесте узгајање различите пољопривредне културе на овој парцели. Тако за 2018. и 2019. годину када је узгајана иста пољопривредна култура (кукуруз) имамо велику корелацију између класа.

Увидом у $R G B$ приказ снимака свих периода за три изабране године и податке о засејаним културама, можемо закључити да расцеп између две зоне земљишта прве класе у 2018. години настаје вероватно као резултат узгајања кукуруза различите сорте на овој парцели, или неких промена у земљишту, што се јасно види на слици 6.

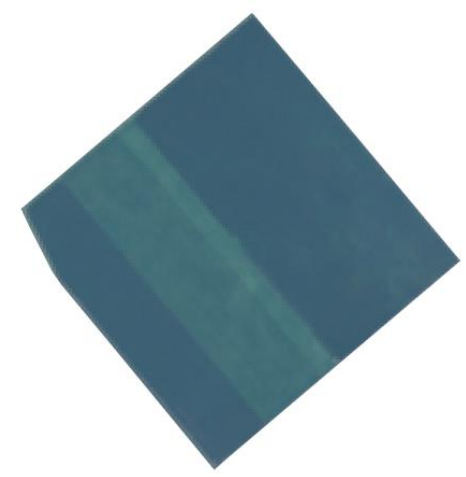

Слика 6. RGB приказ паричеле бр. 21247 за 2018. годину

\section{6. ЗАКљУЧАК}

Даљинска детекција представља веома важну карику у ланцу прецизне пољопривреде и њеним коришћењем је омогућено добијање тачне слике о стању земљишта и усева, то јест планова за селективно прскање корова и инсеката, ублажавање биљних болести, одређивање количине азота, оптимално наводњавање итд. Захваљујући константном развоју технологије она постаје масовно прихваћено решење. У комбинацији са GIS-ом и његовим апликацијама пружа корисне информације широком кругу корисника.

У овом раду дат је предлог решења за зонирање пољопривредног земљишта, то јест за класификацију овог земљишта у одређени број класа спрам стања гајене пољопривредне културе на одређеној парцели и визуелизацију овако добијених података кроз трослојну $G I S$ архитектуру.

При решавању овог задатка увиђени су проблеми који се јављају при једној оваквој анализи и недостаци у алгоритму класификације.
Као главни недостатак алгоритма можемо издвојити проблем са улазним подацима у алгоритам. Ти подаци треба да представљају скуп апсолутно тачних информација о гајеној култури на свакој парцели за анализирану годину, јасно је да нам ови подаци нису увек познати и то представља највећу препреку при анализи земљишта за које ти подаци нису познати.

Наравно велики утицај на класе земљишта имаће разни климатски фактори, ђубрење и наводњавање земљишта који се разликују од године до године.

На основу свега изнетог јасно је да се наведени алгоритам може користити за класификацију пољопривредног земљишта у овој форми, али такође треба размишљати и о његовом унапређењу и проширењу скупа коришћених података при анализи и зонирању земљишта.

\section{7. ЛИТЕРАТУРА}

[1] J.L. Hatfield, A.A. Gitelson, S.J. Schepers, C.L. Walthall, "Application of Spectral Remote Sensing for Agronomic Decisions”, Agronomy Journal 2008.

[2] Д. Јовановић, “Модел објектно оријентисане класификације у идентификацији геопросторних објеката", Нови Сад, Факултет техничких наука.

[3] http://www.esa.int/Our_Activities/Observing_the_Ea rth/Copernicus/Overview3 (приступљено у септембру 2019.)

[4] S.B. Marutirao, „Fundamentals of Biometry“, Ashok Yakkaldevi, 2017.

[5] https://www.euprava.gov.rs/eusluge/opis usluge?gen eratedserviceid=279\&alphabet=lat (приступљено у септембру 2019.)

[6] https://www.indexdatabase.de/ (приступљено у септембру 2019.)

\section{Кратка биографија:}

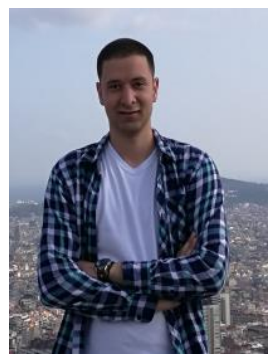

Милан Гавриловић рођен је у Београду 1995. године. Основне академске студије на Факултету техничких наука у Новом Саду, смер геодезија и геоматика, уписао 2014. године. Дипломирао 2018. године и исте године уписао мастер академске студије. Мастер рад на Факултету техничких наука одбранио је 2019. године.

контакт:

milan.gavrilovic995@gmail.com 